\title{
Inhaltsverzeichnis des 112. Bandes
}

\author{
Max von Lane-Festschrift I
}

Ausgegeben am 9. Oktober 1959

Max Born (Bad Pyrmont), Erinnerungen an Max von LAUE's Entdeckung der Beugung von Röntgenstrahlen durch Kristalle .

$J . D$. Bernal (London), Order and disorder and their expression in diffraction . . . . . . . . . . . . . . . . . . . . . . . . .

A. L. Patterson (Philadelphia, Pennsylvania), Function spaces between crystal space and Fourier-transform space . . . . . . . . . . . . .

Leonid V. Azároff (Chicago), Formation, structure, and bonding of Ni-Co-Mn oxides having spinel-type structure. (With 2 figures) . . . . . .

Alfred J. Frueh, Jr. (Oslo), The structure of hessite, $\mathrm{Ag}_{2} \mathrm{Te}-\mathrm{III}$. (With 3 figures) . . . . . . . . . . . . . . . . .

A. Pabst (Berkeley, California), False symmetry, the Templeton effect, in lawsonite. (With 1 figure) . . . . . . . . . . . . . .

Hans Dachs (Upton, New York), Bestimmung der Lage des Wasserstoffe in LiOH durch Neutronenbeugung. (Mit 1 Abbildung) . . . . . . . .

$J$. Monteath Robertson (Glasgow), A study of thermal motion in hydrogenbonded crystals. (With 9 figures) .

H. Jagodzinski (Würzburg), Die Kristallstruktur des AuJ. (Mit 4 Ábbildungen) ..................

$H$. Saalfeld (Würzburg), Einkristalluntersuchungen zum Problem der Hydrargillit-Entwässerung. (Mit 2 Abbildungen). •

Elizabeth A. Wood (Murray Hill, New Jersey), Precession photographs of reciprocal-lattice rods in $\mathrm{HfFe}_{2}$ (With 6 figures) . . . . . . . . .

Dan McLachlan, Jr. (Menlo Park, California), The extension of certain methods of sign determination. (With 4 figures) . . . . . . 108

O. W. Flörke (Würzburg), Regelungserscheinungen bei der paramorphen Umwandlung von $\mathrm{SiO}_{2}$-Kristallen. (Mit 6 Abbildungen) . . . . . 126

G. W. Brindley and M. Nakahira (University Park, Pennsylvania), X-ray diffraction and gravimetric study of the dehydration reactions of

gibbsite. (With 8 figures) $\dot{G} . \dot{N}$. Panagis (Pittsburgh, Pennsylvania),
An experimental study of anomalous x-ray scattering by zinc sulfide and zinc oxide. (With 3 figures) . . . . . . . . . . . . 150

Gabrielle Donnay (Washington, D. C.), J. Wyart and G. Sabatier (Paris), Structural mechanism of thermal and compositional transformations

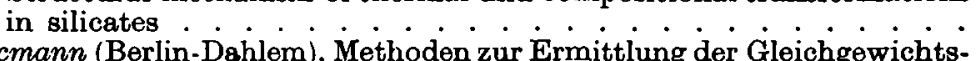

R. Lacmann (Berlin-Dahlem), Methoden zur Ermittlung der Gleichgewichts-
und Wachstumsflächen von homöopolaren Kristallen bei der Adsorption von Fremdstoffen

Kathleen Lonsdale (London), Experimental studies of atomic vibrations in crystals and of their relationship to thermal expansion. (With 1 figure) 188

Joan R. Clark and C. L. Christ (Washington, D. C.), Studies of borate minerals (VIII): The crystal structure of $\mathrm{CaB}_{3} \mathrm{O}_{3}(\mathrm{OH})_{5} \cdot 2 \mathrm{H}_{2} \mathrm{O}$. (With 3 figures) . . . . . . . . . . . . . . . . . . . . .

Isamu Nitta (Osaka, Japan), On the orientational and rotational disorder in molecular crystals. (With 12 figures) . . . . . . . . . . 234 
B. E. Warren (Cambridge, Massachusetts), Small-angle scattering from large volumes. (With 2 figures).

Tom. F. W. Barth (Oslo), The interrelations of the structural variants of the

Mary E. Mrose (Washington, D. C.) and Oleg von Knorring (Leeds, England), The mineralogy of väyrynenite, $(\mathrm{Mn}, \mathrm{Fe}) \mathrm{Be}\left(\mathrm{PO}_{4}\right)(\mathrm{OH})$. (With 3 figures) - · $\cdot \cdot \cdot \cdot \cdot \cdot \cdot \cdot \cdot \cdot \cdot \cdot \cdot \cdot \cdot \cdot \cdot \cdot$

Joachim Stabenow (Berlin-Dahlem), Elektroneninterferenzen an übereinanderliegenden Kristallschichten. I. Orientierte Verwachsung von Mikrokristallen aus Molybdändisulfid. (Mit 5 Abbildungen) . . . .

G. Hildebrandt (Berlin-Dahlem), Gekrümmte Röntgenstrahlen im schwach verformten Kristallgitter. A. Laue-Fall der Interferenz. (Mit 14 Abbildungen) .....................

G. Hildebrandt (Berlin-Dahlem), Gekrümmte Röntgenstrahlen im schwach verformten Kristallgitter. B. Bragg-Fall der Interferenz. (Mit $12 \mathrm{Ab}$ bildungen) . . . . . . . . . . . . . . . . . . . . .

D. R. Fitzwater and $R$. E. Rundle (Ames, Iowa), Crystal structure of hydrated erbium, yttrium and praseodymium ethylsulfates. (With 2 figures). . . . . . . . . . . . . . . . .

K. A. Becker, G. Grosse und K. Plieth (Berlin-Dahlem), Röntgenstrukturanalyse des trans-Dichlorodiäthylendiaminkobalt-III-chlorids. (Mit 8 Abbildungen)

D. W. J. Cruickshank, G. A. Jeffrey and S. $\dot{C}$. Nyburg (Leeds, England), The crystal st.ructure and atomic vibrations of 1,2-diphenyltetra-

D. E. Zuccaro and J. D. McCullough (Los Angeles, California), The crystal structure of trimethylsulfonium iodide. (With 2 figures) . . . - .

Joseph Shropshire, Paul P. Keat and Philip A. Vaughan (New Brunswick,
New Jersey), The crystal structure of keatite, a new form of silica. (With 3 figures) . . . . . . . . . . . . . . . . .

C. A. Beevers and H.W.Ehrlich (Edinburgh), The interpretation of the Pat-

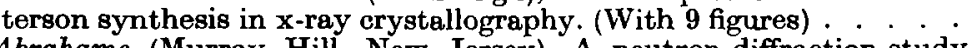

S. C. Abrahams (Murray Hill, New Jersey), A neutron diffraction study of $\mathrm{ZrZn}_{2}$ at $298^{\circ} \mathrm{K}$ and at $5^{\circ} \mathrm{K}$. (With 1 figure)

$S . H$ irokawa, Y. Okaya, $F$. M. Lovell and $R$. Pepinsky (University Park,
Pennsylvania), The crystal structure of aureomycin hydrochloride. (With 13 figures).

W. Cochran (Chalk River, Ontario), Dielectric constants and lattice vibrations of cubic ionic crystals . . . . . . . . . . . . . . . . . . . .

Linus Pauling and Barclay Kamb (Pasadena, California), The discussion of tetragonal boron by the resonating-valence-bond theory of electrondeficient substances. (With 1 figure) . . . . . . . . . . . . .

Autorenregister zu Band 112 . . . . . . . . . . . . . . . . . . . . 4799

Sachregister zu Band 112 . . . . . . . . . . . . . . . . . . . . . . 4800 



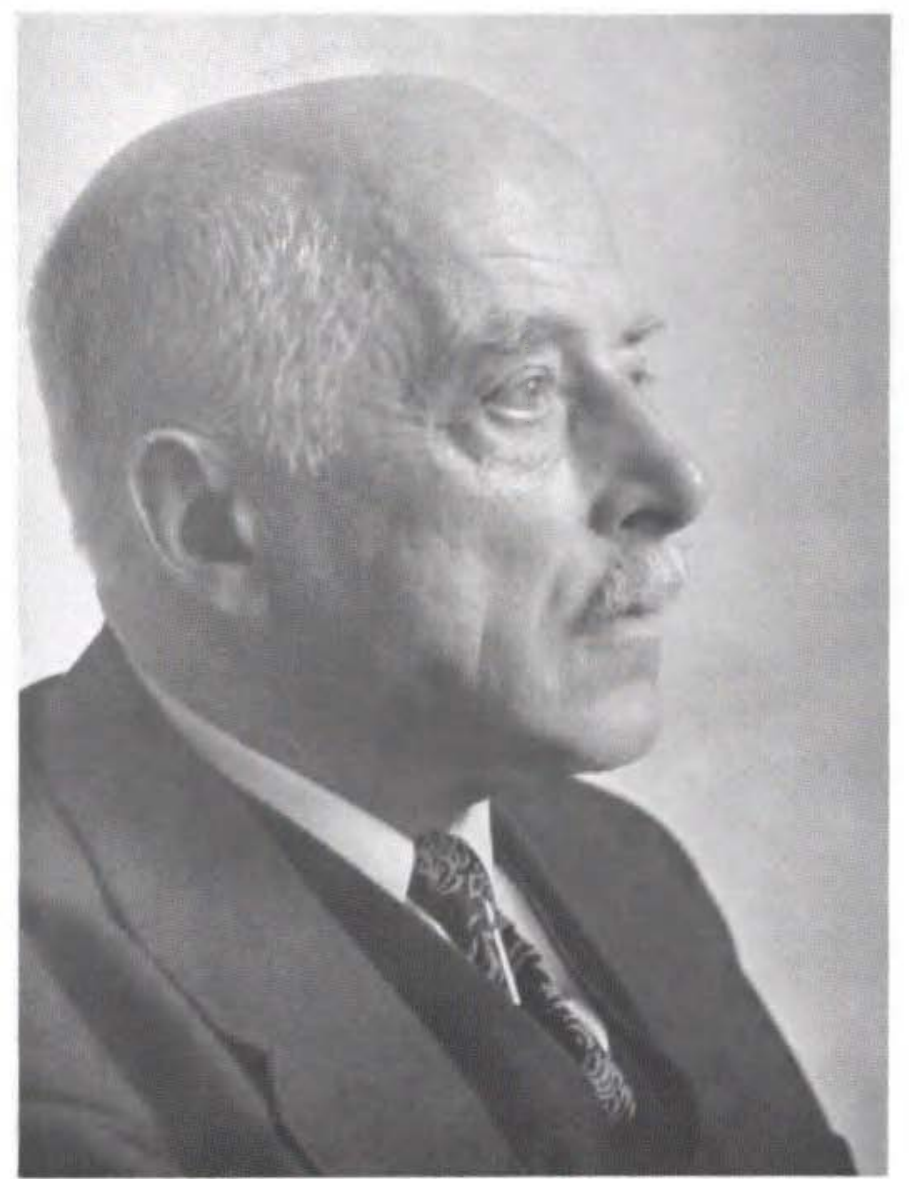

Pboto: Deutsches I usenm, Munchen

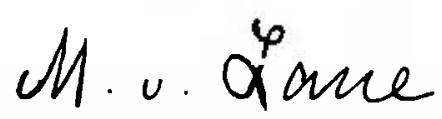

9. $10.1879-9.10 .1959$ 